\title{
METHODOLOGY FOR COMMON RAIL FUEL INJECTORS TESTING IN CASE OF NON-TYPICAL FAULTS
}

\section{Tomasz STOECK}

West Pomeranian University of Technology in Szczecin, Faculty of Mechanical Engineering and Mechatronics, The Department of Automotive Engineering, Piastów Av. 19, 70-310 Szczecin, Poland, e-mail: tstoeck@wp.pl

Abstract

The paper presents the methodology for testing Common Rail fuel injectors, which involved extending standard test procedures with additional measurement points and introducing a linear regression coefficient as a new diagnostic parameter. This allowed for a more precise checking of the fuel dosage method, as the active experiment was conducted at a wider range of nozzle opening times (actuation). The obtained results were used in the calculation stage, which was transferred to the popular spreadsheet environment. This eliminates the need to modify the test bench software. The proposed solution should be particularly useful in problematic situations in which a clear assessment of the technical condition of the fuel injector remains difficult, as shown in the example.

Keywords: Common Rail fuel injector, extension of test procedures, fuel dosage

\section{METODYKA BADAŃ WTRYSKIWACZY PALIWA COMMON RAIL W PRZYPADKU WYSTĘPOWANIA USTEREK NIETYPOWYCH}

\section{Streszczenie}

W artykule przedstawiono metodykę badań wtryskiwaczy common rail, która polegała na poszerzeniu standardowych procedur testowych o dodatkowe punkty pomiarowe i wprowadzeniu współczynnika regresji liniowej jako nowego parametru diagnostycznego. Pozwoliło to na bardziej precyzyjne sprawdzenie sposobu dawkowania paliwa, gdyż eksperyment czynny prowadzono przy szerszym zakresie czasów otwarcia rozpylacza (wysterowania). Uzyskane wyniki wykorzystano w fazie obliczeniowej, którą przeniesiono do środowiska popularnego arkusza kalkulacyjnego. W ten sposób wyeliminowano konieczność modyfikacji oprogramowania stołu probierczego. Proponowane rozwiązanie powinno być szczególnie przydatne w sytuacjach problematycznych, w których jednoznaczna ocena stanu technicznego wtryskiwacza pozostaje utrudniona, co pokazane zostało na przykładzie.

Słowa kluczowe: wtryskiwacz common rail, rozszerzenie procedur testowych, dawkowanie paliwa

\section{INTRODUCTION}

The most reliable and precise method of diagnosing Common Rail fuel injectors are bench tests [8]. They are carried out on special test benches, enabling measurements in automatic cycles or at manual settings. Standard procedures require checking of fuel dosage at several critical work points, i.e. at fuel injection pressures and nozzle opening times (actuation) in accordance with the manufacturer's recommendations. Typically, these tests allow for correct verification and assessment of the technical condition of the fuel injector [9]. However, there are problematic situations in which even a positive test result is not sufficient. It may turn out that the valuesof fuel consumption are incorrect in other engine working areas. Detection of these irregularities forces the necessity to prepare a full injection characteristics (map), examples of which were presented in the source literature $[10,11,17,18]$. Despite the undoubted benefits, this function is used sporadically and only in justified cases, primarily due to the significant nuisance of the active experiment. The results are obtained with a very wide spectrum of input parameters, which means that the time consumption of this stage increases almost 4 times compared to the manufacturer's tests.

The proposed methodology supplements and develops the concept that was presented in the publication [3]. It consisted of a slight increase in the number of measurements carried out in the immediate vicinity of the base points, followed by the determination and comparison of the slope of selected sections of the fuel dosage characteristics of the tested fuel injector with the reference one. Unfortunately, to date, this solution has not found wider application in car repair shop and laboratory practice. No software was made available for test benches, which would include a linear regression coefficient as a new diagnostic parameter. 
Nevertheless, an attempt to optimise standard tests seems to be so interesting and effective that it was decided to return to it. In the author's opinion, the calculations can be carried out in the environment of the popular Microsoft Excel spreadsheet. Thanks to the implemented mathematical formulas, this process is not difficult, and the final results are obtained right after the end of the experiment. In addition, the input data can come from any test benches, as there is no need to generate a full injection map. This function is only available on selected test benches, e.g. STPIW-3 from Autoelektronika Kędzia Automotive Training Centre in Poznań [13].

\section{RESEARCH METODS}

The tests were carried out on the example of a Denso electromagnetic fuel injector, the cross section of which is shown in Figure 1.

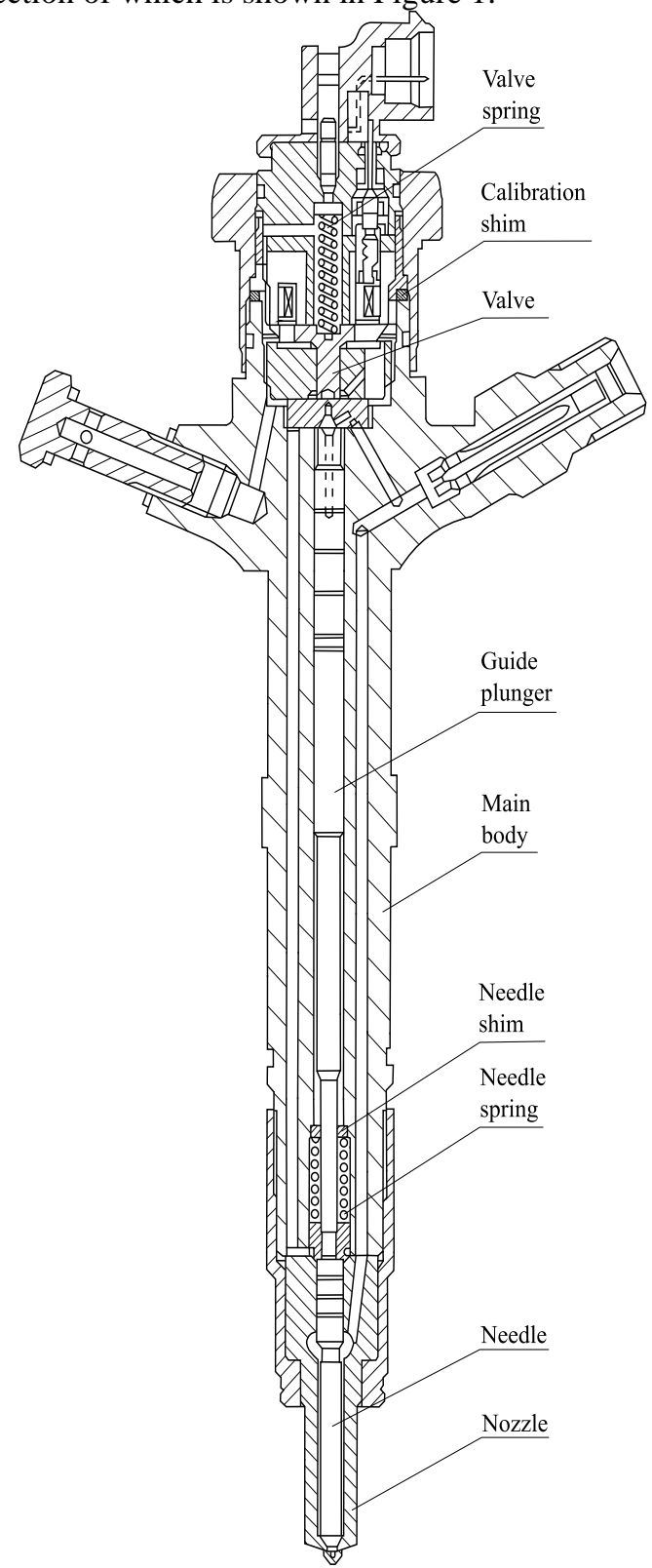

Fig. 1. Construction of the Denso fuel injector [15]
The fuel injector was dismantled from a 2.2 HDI (High-pressure Direct Injection) diesel engine of the Citröen Jumper II delivery van with an operational mileage of 134 thousand kilometres. Its construction and principle of operation is analogous to that in Bosch CR1 constructions [19]. The difference is a different variant of the valve assembly, in the spindle of which a semi-ball is mounted. Nevertheless, visual inspection and verification of individual components is similar, i.e. taking into account the wear of the needle, nozzle tip, guide piston and control assembly. The reason of partial or total dismantling depends on the results of preliminary tests.

\subsection{Test benches}

The tests were carried out at the engine laboratory benches of the Department of Automotive Engineering of the West Pomeranian University of Technology (ZUT) in Szczecin. The following apparatus and instrumentation were used in individual stages:

- Carbon Zapp Diesel Tech CRU.2 test bench (Fig. 2),

- laboratory microscope SZM-168 (Fig. 3),

- digital micrometer IP54,

- ultrasonic baths (Elma Elmasonic S 10 H, Carbon

Tech Ultrasonic Bath S15/C2),

- vices and kits for disassembly and assembly of the fuel injector into components,

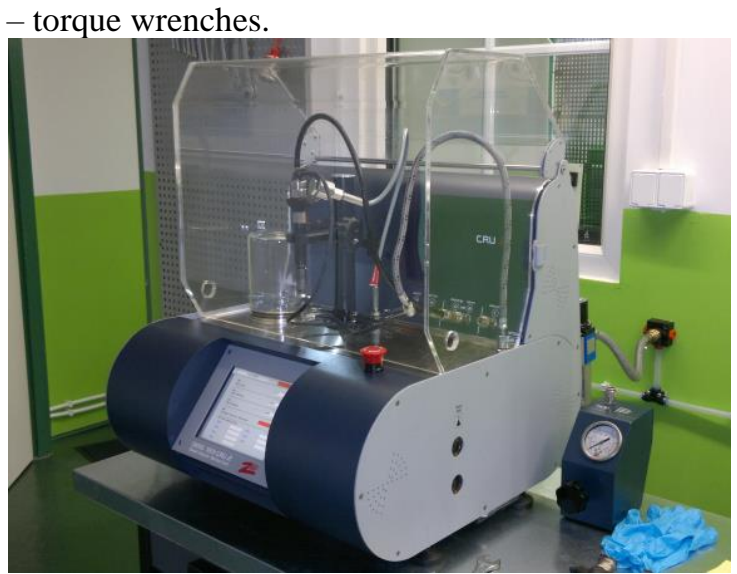

Fig. 2. Carbon Zapp Diesel Tech CRU.2 test bench

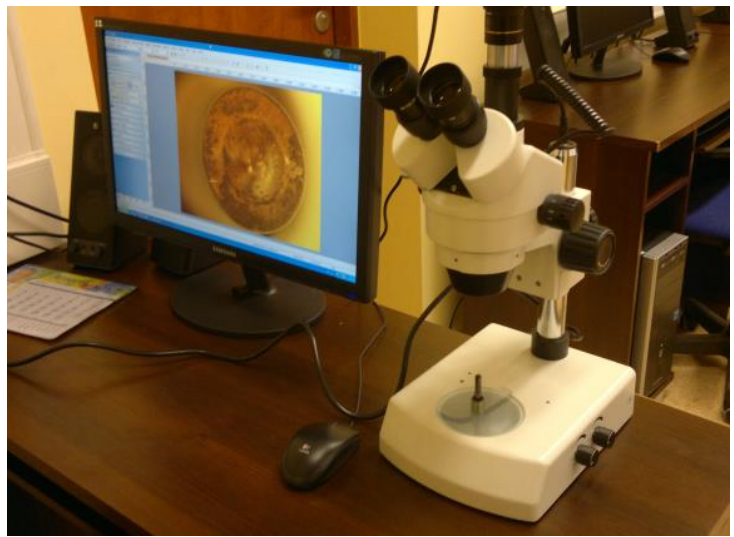

Fig. 3. Laboratory microscope SZM-168 


\subsection{The scope of preliminary tests}

After disassembly from the engine, an external inspection of the fuel injector was carried out, which consisted of visual assessment and checking the completeness of the components. The number was also read from the main body and entered into the memory of the test bench. Before starting the preliminary tests, thermochemical flushing was performed, i.e. the process of cleaning under high pressure and elevated detergent temperature. This decision was made due to the relatively small operational mileage (duty cycle) of the fuel injector, the incorrect operation of which could have been caused by the occurrence of internal deposits of the IDID (Internal Diesel Injector Deposit) type. Their presence negatively affects the method of fuel dosage, reducing the dynamics of movable controls and actuators [2, 4, 14].

In the next step, the following types of tests were performed: electrical test "eRLC" (Resistance, Inductance, Capacitance), leak test "LKT" (Static Leak Test) and nozzle opening pressure test "NOP" (Nozzle Opening Pressure). In addition, volume measurements "IVM" (Injector Volume Metering) were carried out in automatic mode. These are standard work points, implemented in accordance with the manufacturer's guidelines, corresponding to the work of the fuel injector under [7]:

- full load VL (German: Voll last),

- half load EM (German: Emissionpunkt),

- idling LL (German: Leer lauf),

- pre-injection / extra injection VE (German: Vor lauf).

\subsection{The scope of basic tests}

In accordance with the adopted methodology, the scope of basic tests was expanded to include additional measurements that were carried out in a relatively immediate vicinity of the base points of $(\mathrm{t}= \pm 50 \mu \mathrm{s})$. The time distance was chosen in such a way that the results obtained can be connected using straight lines, determined from linear regression equations. For this purpose, the experimental data were entered into a Microsoft Excel spreadsheet. Since in the analysed case there was only one variable, the sought relationship was presented in the form:

$$
\mathrm{d}=\mathrm{at}+\mathrm{b}
$$

In the calculations, built-in statistical functions with similar syntax were used, which allowed the determination of the slopes a and $b$. These were the following formulas, respectively [1]:

$$
=\operatorname{SLOPE}(\text { known_d`s; known_t`s })
$$

and

$$
=\text { INTERCEPT(known_d`s; known_t`s) }
$$

Identical values can be obtained using the predefined function (array formula) LINEST. This alternative determination of the slope and the intercept with the axis $d$ required the use of the following syntax [12]:

$$
=\text { INDEKS(LINEST(known_d`s; known_t`s); 1) }
$$

and

$=$ INDEKS(LINEST(known_d`s; known_t`s); 2) (5)

The final results were compared with the standard slopes, which were estimated on the basis of the average results of measurements carried out for a set (4 pieces) of brand new Denso fuel injectors.

\section{RESULTS AND DISCUSSION}

Table 1 summarises the results of the preliminary tests that were carried out after the internal cleaning was completed. The fuel injector was considered fully operable, as the obtained values were in accordance with the manufacturer's recommendations. However, after the assembly stage, the engine worked unevenly, especially at idle and at low loads. Such symptoms could indicate the occurrence of malfunction, which is associated with the frictional wear of the plunger and barrel assembly [5, 6]. In a situation where this process is in the initial phase, the fuel dosage disturbance occurs when the injection pressure is low. However, with the increase of this parameter, the needle lift in the nozzle is not impeded and it overcomes the resistance of the needle spring without obstacles [16]. This is confirmed by the graphical interpretation of the results of the "iVM" volume test, which is shown in Figure 4. It is worth noting that the point of actual fuel consumption at idle $\left(\mathrm{p}_{\mathrm{inj}}=25 \mathrm{MPa}, \mathrm{t}=710 \mu \mathrm{s}\right)$ is at the very edge of the range, but within the limits of permissible

\begin{tabular}{|c|c|c|c|}
\hline \multicolumn{3}{|c|}{ Test type } & Result \\
\hline \multirow{3}{*}{$\begin{array}{l}\text { Electric } \\
\text { test } \\
\text { eRLC }\end{array}$} & \multicolumn{2}{|c|}{ Coil resistance, $R_{c}[\Omega]$} & 0,7 \\
\hline & \multicolumn{2}{|c|}{ Coil inductance, $L[\mu \mathrm{H}]$} & 178 \\
\hline & \multicolumn{2}{|c|}{ Winding faulted to frame } & Not found \\
\hline \multicolumn{3}{|c|}{$\begin{array}{l}\text { Leak Test LKT } \\
{[\mathrm{MPa}]}\end{array}$} & 89,4 \\
\hline \multicolumn{3}{|c|}{$\begin{array}{l}\text { Nozzle Opening Pressure test } \\
\text { NOP [MPa] }\end{array}$} & 16,50 \\
\hline $\begin{array}{l}\text { Dose } \\
\text { type }\end{array}$ & $\begin{array}{l}\text { Injection } \\
\text { pressure, } \\
\text { pinj }_{\text {in }}[\mathrm{MPa}]\end{array}$ & $\begin{array}{c}\text { Nozzle } \\
\text { opening } \\
\text { times } \\
\text { (actuation), } \\
\mathrm{t}[\mu \mathrm{s}]\end{array}$ & $\begin{array}{l}\text { Nominal and } \\
\text { actual dose, } \\
\text { d [mg/stroke] }\end{array}$ \\
\hline VL & 160 & 910 & $\begin{array}{c}47,74 \pm 6,93 \\
48.95\end{array}$ \\
\hline EM & 80 & 720 & $\begin{array}{c}18,28 \pm 4,20 \\
18,6\end{array}$ \\
\hline LL & 25 & 710 & $\begin{array}{c}3,90 \pm 1,84 \\
2,14\end{array}$ \\
\hline VE & 80 & 320 & $\begin{array}{c}1,84 \pm 1,22 \\
1,73\end{array}$ \\
\hline
\end{tabular}
deviation. Therefore, this fuel injector malfunction has not been detected in the standard procedure.

Table 1 . Results of the preliminary tests

Considering the obtained results, it was decided that the basic tests would concern only the LL dose. Therefore, additional measurements were carried out on the test bench, setting the following nozzle opening times $\mathrm{t}[\mu \mathrm{s}]: 660$ and 760 . 


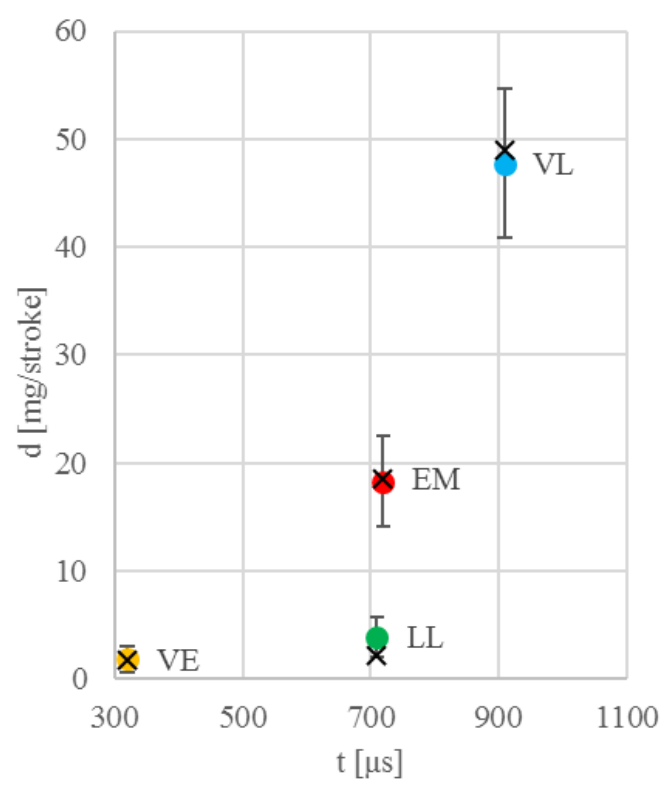

Fig. 4. Graphic interpretation of the "iVM" test

In the next step, the calculation stage started, which began with entering cell addresses into formulas (1) and (2). This procedure allowed to estimate the value of slopes of the sought linear regression equation:

$0,0016=\operatorname{SLOPE}(2,06: 2,22 ; 660: 760)$ and

1,004=INTERCEPT $(2,06: 2,22 ; 660: 760) \quad$ (7)

The obtained results were checked in the similar way, using the syntax (4) and (5):

0,0016=INDEKS(LINEST $(2,06: 2,22$; 660:760); 1)

and

\section{1,004=INDEKS(LINEST(2,06:2,22;} 660:760); 2)

Figure 5 shows a graphical method to verify fuel dose at idle.

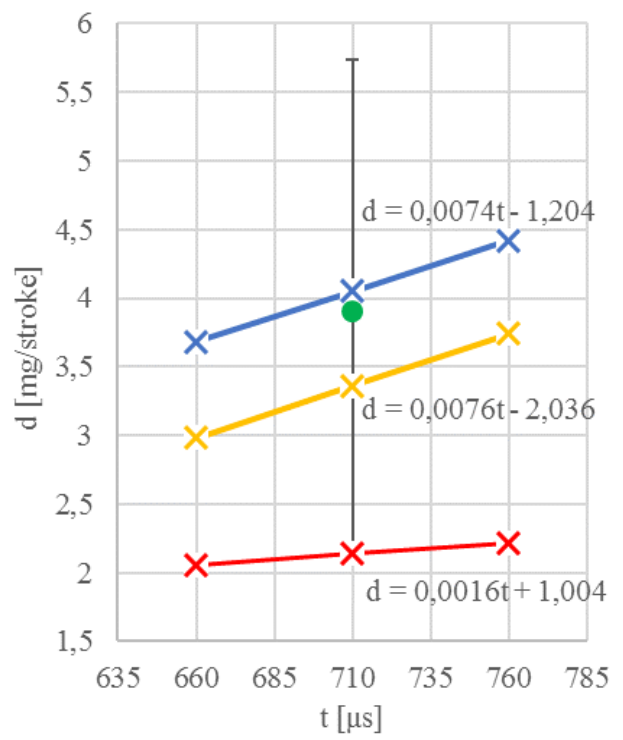

Fig. 5. LL dose verification method

A significant difference can be seen in the slope of the reference line and the one that represents the fuel injector under test (before repair). This is because different values of the slopes a were obtained, which amounted to 0.0074 and 0.0016, respectively (Table 2 ). In this case, the result of the extended test procedure was assessed negatively, regardless of the actual value of fuel consumption.

Table 2. The results of basic tests

\begin{tabular}{|c|c|c|c|}
\hline \multirow{2}{*}{$\begin{array}{c}\text { Nozzle } \\
\text { opening times, } \\
\mathrm{t}[\mu \mathrm{s}]\end{array}$} & $\begin{array}{c}\text { Before } \\
\text { repair }\end{array}$ & $\begin{array}{c}\text { After } \\
\text { repair }\end{array}$ & $\begin{array}{c}\text { Reference } \\
\text { line }\end{array}$ \\
\cline { 2 - 4 } & \multicolumn{3}{|c|}{$\begin{array}{c}\text { Actual dose, } \\
\mathrm{d}[\mathrm{mg} / \mathrm{stroke}]\end{array}$} \\
\hline 660 & 2,06 & 2,98 & 3,68 \\
\hline 760 & 2,22 & 3,74 & 4,42 \\
\hline \multicolumn{4}{|c|}{ Slopes } \\
\hline $\mathrm{a}$ & 0,0016 & 0,0076 & 0,0074 \\
\hline $\mathrm{b}$ & 1,004 & $-2,036$ & $-1,204$ \\
\hline
\end{tabular}

The repair process required disassembly of the nozzle assembly, followed by washing of the components in ultrasonic baths and subjecting them to microscopic examination.

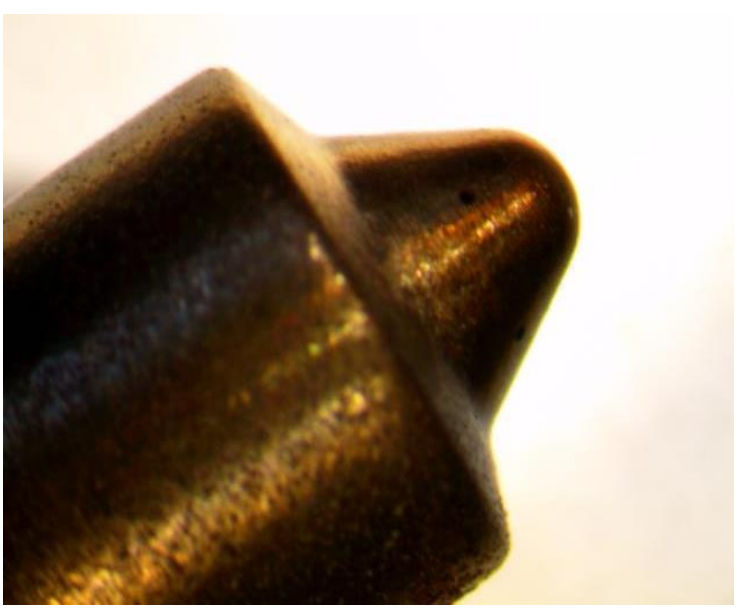

Fig. 6. Nozzle tip

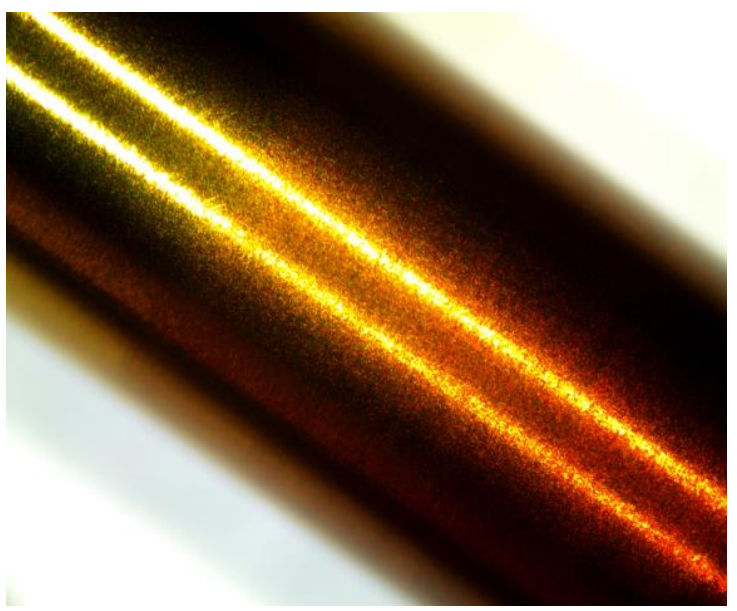

Fig. 7. Working surface of the nozzle needle

During the inspection under high magnification, no damage to the nozzle tip was found (Fig. 6). On the other hand, in the case of the needle, slight changes in its working surface were observed, as 
well as local thermal discolouration (Fig. 7). They may indicate overheating of the contact zones as a result of combusting too lean fuel-air mixtures [13]. However, it was decided that the plunger and barrel assembly does not need to be replaced and may be allowed to continue operation.

The LL dose adjustment was carried out by replacing the needle washer whose thickness was changed from $1.34 \mathrm{~mm}$ to $1.26 \mathrm{~mm}$. In this way, the preload of the lower spring, which stopped limiting the needle lift at low pressure and, as a result, the amount of fuel injected, was reduced. The final effect is illustrated by a straight line which was plotted on the basis of measurements and calculations made after the repair (Fig. 5). Its slope and intersection with the axis $d$ is close to the reference line, therefore the tested fuel injector was found to be technically sound. Otherwise, the needle with the nozzle should be replaced or an attempt should be made to increase the thickness of the calibration washer under the solenoid coil nut (Fig. 1). It should be noted, however, that such a regulation would affect the value of other fuel doses, which would require checking them.

\section{CONCLUSION}

The presented methodology is more accurate than standard test procedures, in which only selected Common Rail fuel injectors are checked. The introduction of a new diagnostic parameter, i.e. a linear regression coefficient, enabled the detection of problematic faults without having to generate a full injection map. This is important from the point of view of the time-consumption and nuisance of the experimental stage, as the number of additional measurements relates only to questionable base points, as shown in the example. In addition, in car repair shop and laboratory practice there is no need to use graphic interpretation at all, and the diagrams presented in the paper are for reference only. The added value is also the method of conducting calculations, which was entirely carried out in a spreadsheet environment, by definition eliminating the need to modify the test bench software. Thanks to this approach, the discussed method has a chance to be disseminated on a wider scale.

A certain disadvantage in the basic tests is the condition of switching from automatic mode to manual settings. This is important when we have an advanced multi-section sampler that allows the simultaneous testing of several fuel injectors, e.g. Carbon Zapp Diesel Tech CRU.4, Bosch EPS780. However, it should be emphasised that non-typical faults are rarely considered within a set from one engine. Therefore, setting additional measuring points and conducting calculations should not be troublesome for individual cases. In addition, there is no change in the stage of preliminary tests, which is entirely carried out in an automated manner.

\section{REFERENCES}

1. Alexander M, Kusleika D. Excel ${ }^{\circledR} 2016$ Formulas. Indianapolis: John Wiley \& Sons, Inc.; 2016.

2. Berndt S, Schümann U, Sadlowski T, Buchholz B. Development of a laboratory test for the deposit forming tendency of diesel fuels. ATZ offhighway worldwide 2018; 11: 50-55.

https://doi.org/10.1007/s41321-018-0006-2

3. Busz W, Walaszczyk A. Optimize the testing process common rail fuel injectors. Combustion Engines 2015, 162(3): 978-981. Polish.

4. Corbett PJ, McIntosh AJS, Gee M, Hallett JP. Use of ionic liquids to minimize sodium induced internal diesel injector deposits (IDIDs). Molecular Systems Design \& Engineering 2018; 3: 397-407. https://doi.org/10.1039/C7ME00110J

5. Ignaciuk P, Gil L. Damages to injectors in diesel engines. Advances in Science and Technology Research Journal 2014; 21(8): 58-61. https://doi.org/10.12913/22998624.1091880

6. Juściński S, Piekarski W, Chomik Z. Analysis of injection systems types used in agricultural machines. Agricultural Engineering 2017; 21(4): 37-46. https://doi.org/10.1515/agriceng-2017-0034

7. Karpiuk W, Bor W, Smolec, R. Possibilities of Analysis of Condition and Repair of Common-Rail System Injectors. Journal of KONES Powertrain and Transport 2018; 23(4): 209-216. https://doi.org/10.5604/12314005.1217208

8. Kluczyk M, Grządziela A. Marine diesel engine common rail injectors monitoring with vibration parameters. Diagnostyka 2019; 19(3): 37-44. prhttps://doi.org/10.29354/diag/109793

9. Kneba Z, Straszak P, Jakóbczyk K. The effectiveness of fault detection in common rail injectors examination methods. Combustion Engines 2017; 170(3): 49-56.

http://dx.doi.org/10.19206/ce-2017-308

10. Krivtsov SN, Yakimov LV, Ozornin SP. Numerical analysis and experimental studies on solenoid common rail diesel injector with the worn control valve. IOP Conference Series: Materials Science and Engineering 2018; 327(4): 42-57. https://doi.org/10.1088/1757-899X/327/4/042057

11. Lechner R, O'Connell N, Neumann J, Daschner R. Hydraulic injection characteristics of different biofuels. Journal of Fundamentals of Renewable Energy and Applications 2017; 7(4): (Suppl). https://doi.org/10.4172/2090-4541-C1-029

12. McFedries P. Excel ${ }^{\circledR} 2016$ Formulas and Functions. Indianapolis: Pearson Education, Inc.; 2016.

13. Osipowicz T, Kowalek S. Evaluation of modern diesel engine fuel injectors. TEKA. Commission of Motorization and Energetics in Agriculture 2014; 14(3): 83-88.

14. Stępień Z. A study of factors influencing the formation of harmful deposits in the diesel engine injectors. Eksploatacja i Niezawodność Maintenance and Reliability 2017; 19(3): 331-337, http://dx.doi.org/10.17531/ein.2017.3.3

15. Stoeck T. Application of the experimental design technique in fuel dose adjustment of common rail injector. Combustion Engines 2019; 179(4): 210-215. https://doi.org/10.19206/CE-2019-435

16. Stoeck T, Osipowicz T, Abramek KF. Methodology for the repair Denso Common Rail solenoid injectors. 
Eksploatacja i Niezawodność - Maintenance and Reliability 2014; 16(2): 270-275.

17. Śmieja M, Wierzbicki S, Mamala J. Sterowanie dawką wtryskiwanego paliwa w układzie Common Rail z wykorzystaniem środowiska LabView. Combustion engines. 2013;154(3):542-548.

18. Vasiliu D, Vasiliu GC, Râdulescu A, Cojocaru Greblea T. Predicting the dynamic performance of the fuel injectors by numerical simulation. U.P.B. Scientific Bulletin, Series C: Electrical engineering and Computer Science 2018; 78(4): 173-188.

19. Yordanov N, Hadjiev K, Stankov E. Experimental simulation of common rail electromagnetic injectors wearing. International Scientific Journal "Machines, Technologies, Materials" 2018; 12(4): 208-211.

Received 2020-02-13

Accepted 2020-05-05

Available online 2020-05-06

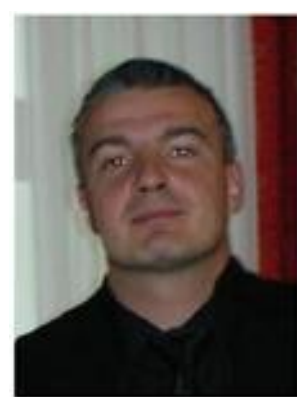

Tomasz STOECK, Ph.D. graduated from the Faculty of Mechanical Engineering of the Szczecin University of Technology (currently ZUT in Szczecin) in the field of Machine Construction and Operation. For many years, he has been conducting scientific research related to the diagnosis and repair of fuel injection

systems for diesel engines. 